

\section{Guitarra rota}

\section{Diego Romero}

Y los hombres siguen aferrados a la ilusión contra la sospecha de que las cosas son de otro modo y de que ellos viven de una maldición. Maldición del error. El error de la maldición. El maldito error de nuestra reacción ante lo que sucede. La naturaleza ofrece su cara ciega y la guitarra su rostro mudo de música. Pensar de esta fotografía como la falta del hombre, su ausencia vital en aquello que era suyo. Lo roto, la basura a quemar, es el frío rastro de su espíritu, es la arqueología mojada e inútil de sus instrumentos insuperablemente mal puestos, en una costa mal puesta, en la medida del hombre. Para no ser malditos vivimos como ilusos.

La guitarra, arma de malditos osados que cantaron al hombre frente al hombre, es una fragilidad sin las manos. Como sea, se ha visto en ese barro algo natural, se ha alejado del hombre y de su huida a lo idéntico. Esa guitarra no podrá manifestar a nadie, no sirve de nada, no es guitarra. Se libró atrofiada de su relación productiva. ¡Qué inmadurez para desarmarse! ¡Qué signo de lo imprevisto!

Entonces al dejar caer en el olvido, al admitir y reconocer lo no iluminado por el hombre, no queda más que pensar que el mástil de la guitarra apuntaba hacia la dirección de la ola, no quedaba otra cosa que salvar la clavijas. ¿No es acaso un límite del acuoso pensamiento, lo roto? No hay una inusitada intención de comprender; lo roto es un margen del vivir, es lo poderoso que esconde el paso del tiempo, de las olas, de un descuido. No hay ambición sobre lo roto. Y tampoco es probable lo contrario: el hecho de que sea algo carente de significación, desterrada de la espiritual, es más bien, un signo atrofiado, una sombra, una huella, una ruina de una antigua cultura perdida entre el mar y la costa, tendida a desaparecer.

Y nadie desconoce que una guitarra se parece a las gigantes olas cuando está plena, reteniendo la expectativa futura a la próxima vibración, formando un remolino al centro del pueblo, en la plaza de los hombres, donde reúnen su cansancio, donde 
todo se convoca; autos, baños, muñecos, botellas, niños muertos, cortinas, colchones, libros, cuadros, la misma guitarra como la imagen pálida de un músico entre las curvas aguas, como la imagen concreta de las curvas rotas de la guitarra. Al centro del remolino, el espíritu universal y la materialidad del hombre.

- ¡Oye, hija, como canta la sirena de la mar!

Un bombero riendo y bailando en el centro del remolino, sosteniendo el cuerpo de un instrumento de cuerdas. Entre las habitaciones, un cuerpo sonoro alcanza a secarse, medio pandero no molesta oxidado. Otras guitarras han vuelto a sonar frente al fuego, como un terremoto, porque el terremoto deviene sonoro y los hombres gustan de visitar sus ruinas, y es menos terrible cuando no es él quien arrasa. Es momento de reaccionar, volcar con la vida lo que la institución no podrá hacer, expresar lo que sucede, sucediendo. Y no hay que detenerse en la forma, hay un devenir terremoto en la ciudad limpia. ¿Qué hacemos con nuestros muertos? ¿Qué hacemos con lo roto, si se niega a quemarse?

Lo que está pasando es la guitarra en su transcurso, es el final de un viaje, una estructura de la madera que viene y va por la modificación de sus potenciales sonidos. Una cuerda más, una tamaño diferente. La guitarra rota es el quiebre, el contrapunto con el caos de las cosas. Manchada con el arrebato, es el arrebato mismo; por eso, lentamente, esa guitarra será depositada, arrastrada más bien, a una pila de cosas rotas, donde el fuego se encarga de consumir lo que tiene que volver a consumirse.

Para recibir sin error la maldición pretenciosa de nuestro orden, un arpegio roto podría ser compuesto, un arpegio que alcanzara sus ganas de desaparecer. El canto del terremoto podría tener algo de ese arrebato mojado, mascando con sus cuerdas podría romper las conciencias libres del terremoto. Augurar ese despego errante de las cosas, cuando la vida vale más que una casa, que un auto, que una sosegada guitarra. El canto podría tomar el rostro turbulento del mar, colmar a la gente de su basura, romper lo bello sin distinción, abofetear sin pedir permiso.

-Y nos comimos la pierna de una animal muerto en la playa.

Vida a la muerte, muerte a la vida. Canto imprevisto, un arpegio que se imponga: yo no sé donde está lo que cuidaba, o yo voy a llegar cuando no te des cuenta. Tal vez, rescatar del 
terremoto de nuestra memoria esos ritmos de convulsión en un aliento mimético.

Entonces donde termino el mundo, vamos y volvemos con la naturaleza en las manos, no hay que ilustrar a la ilustración con la imagen de su distancia falsa, habría que trabajar con lo impredecible, un terrorismo de la basura, un canto del catastro de sus reacciones de voluntad ciega, de lo inconcluso que es la vida al otro lado de una pantalla, donde lo roto no tiene olor, donde no hay más que un intento de explicar lo que debería tener el carácter de lo no pensado. Atentar justo cuando no es el hombre quien interviene en el hombre. Gritar lo que la vida gritó cuando se rompe ella misma sin proponerse el porqué.

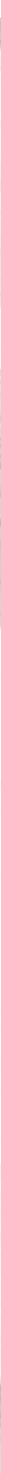

